23

\title{
Водорастворимые KT InP/ZnS как маркеры дибутилфталата. Влияние спирта на растворимость фталатов
}

\author{
(C) А.С. Кулагина ${ }^{1,2 \uparrow, ~ В . В . ~ Д а н и л о в ~}{ }^{3}$, В.Б. Шилов ${ }^{4}$ \\ ${ }^{1}$ Санкт-петербургский национальный исследовательский академический университет им. Ж.И. Алферова РАН, \\ 194021 Санкт-Петербург, Россия \\ ${ }^{2}$ Физико-технический институт им. А.Ф. Иофффе РАН, \\ 194021 Санкт-Петербург, Россия \\ ${ }^{3}$ Петербургский государственный университет путей сообщения Императора Александра I, \\ 190031 Санкт-Петербург, Россия \\ ${ }^{4}$ АО „ГОИ им. С.И. Вавилова“, \\ 199053 Санкт-Петербург, Россия \\ ฯ e-mail: a.s.panfutova@gmail.com
}

Поступила в редакцию 03.02.2021 г.

В окончательной редакции 03.02.2021 г.

Принята к публикации 18.02.2021 г.

Исследовано взаимодействие полупроводниковых водорастворимых квантовых точек (КT) InP/ZnS-PEG$\mathrm{COOH} \mathrm{с} \mathrm{дибутилфталатом} \mathrm{(ДБФ)} \mathrm{в} \mathrm{пробах} \mathrm{пресной} \mathrm{и} \mathrm{морской} \mathrm{воды.} \mathrm{Обнаружено,} \mathrm{что} \mathrm{увеличение}$ концентрации ДБФ в растворе пресной воды с КТ InP/ZnS приводит к росту амплитуды люминесценции КТ. Рост амплитуды люминесценции вызван локализацией молекул ДБФ в полости Онзагера КТ и пассивацией ее поверхности. Повышение концентрации этилового спирта повышает растворимость ДБФ и может служить средством повышения чувствительности при регистрации фталатов в водных средах. Наблюдения за динамикой люминесценции в образцах воды Черного, Средиземного и Белого морей показали индивидуальный характер взаимодействия КТ InP/ZnS с ДБФ, в том числе при увеличении концентрации этанола. Установлено, что пластиковая упаковка, содержащая внутри себя вещества, в составе которых присутствует спирт, является потенциально опасной для здоровья человека.

Ключевые слова: качество воды, водорастворимые квантовые точки $\mathrm{InP} / \mathrm{ZnS}$, дибутилфталат, спектры поглощения, люминесценция.

DOI: $10.21883 /$ OS.2021.06.50995.1878-21

\section{Введение}

Сегодня остро стоит вопрос о качестве воды, которую мы пьем и которая нас окружает. Повсеместно распространено использование пластиковых контейнеров для хранения воды, алкоголя, продуктов. Однако выделение в контактирующую среду продуктов разложения пластика - фталатов - может происходить под влиянием многих факторов [1]. В настоящее время в Европейском Союзе и Канаде в целях заботы о здоровье нации запрещено содержание фталатов в детских игрушках и продуктах [2]. Фталаты, имитирующие структуру эстрогена, могут вызывать нарушения в эндокринной системе. Будучи канцерогенами фталаты накапливаются в организме человека [3].

Продукты жизнедеятельности разлагающих пластик бактерий, среди которых присутствуют фталаты, могут повлиять на морскую экосистему, а также, поднимаясь по пищевой цепочке, вернуться к человеку [4]. По имеющимся сведениям [5] на сегодняшний день основной вклад в загрязнение потребительского молока вносят дибутилфталат (ДБФ) и диметилфталат.

В медицине метаболиты фталатов анализируют с помощью жидкостной хроматографии и тандемной масс- спектроскопии [6]. Такой химический анализ дорог и сложен, что ограничивает список подходящих лабораторий до небольшого числа специальных центров. Миниатюризации приборной базы можно достичь с помощью использования наноструктур. Известно, что изменение спектральных свойств наночастиц служит индикатором их взаимодействия с различными агентами [7,8]. Известно, что водорастворимые квантовые точки (КT) InP/ZnS обладают высоким квантовым выходом люминесценции, одновременно малой токсичностью для биологического применения и высокой реакционной способностью к изменению окружения [9].

Целью настоящей работы являлось исследование взаимодействия KT InP/ZnS с ДБФ в пробах пресной и морской воды, а также изучение влияния содержания спирта на растворимость фталатов. Подобное исследование перспективно с точки зрения разработки метода экспресс-диагностики фталатов в жидких средах.

\section{Материалы и оборудование}

Согласно техническому регламенту ТР ТС 005/2011 „О безопасности упаковки“, тара, предназначенная для 
пищевой продукции, не должна выделять в контактирующие с ней среды вещества, вредные для здоровья человека, в количествах, превышающих предельно допустимые значения; по ДБФ совсем не допускается его миграция в контактирующие среды [1,3]. Поэтому в качестве объекта исследования был выбран ДБФ (дибутилбензол1,2-дикарбонат, DBP - анг.) $\mathrm{C}_{6} \mathrm{H}_{4}\left(\mathrm{COOC}_{4} \mathrm{H}_{9}\right)_{2}$ - дибутиловый эфир фталевой кислоты. В качестве маркеров фталатов использовались полупроводниковые водорастворимые КT InP/ZnS, покрытые лигандами PEG $\mathrm{COOH}$ производства Mesolight. Максимум люминесценции КТ приходился на область $630 \mathrm{~nm}$. Исходная концентрация КТ во всех исследуемых растворах составляла $C \approx 7 \cdot 10^{-8}$ М. В качестве пресной воды использовалась водопроводная вода, пропущенная через фильтр Аквафор. Образцы морской воды были взяты из Черного (г. Геленджик, соленость $\sim 18.0 \%$ ), Белого (г. Беломорск, соленость 24.0-30.0\%) и Средиземного морей (западное побережье о. Гозо, Мальта, соленость $36.0-39.5 \%)$.

Спектры поглощения и люминесценции регистрировались с помощью спектрофотометра UV-probe 3600 (Shimadzu) и спектрофлуориметра Cary Eclipse (Varian). Возбуждение люминесценции производилось на длине волны $\lambda=405 \mathrm{~nm}$.

\section{Результаты и обсуждение}

\section{Исследование взаимодействия КТ и ДБФ в пресной воде}

На рис. 1 представлены результаты исследований спектральных характеристик КT InP/ZnS при взаимодействии с ДБФ в растворах с пресной водой. При малых концентрациях ДБФ скапливался в виде жировых капель на поверхности водного раствора. Начиная с $6 \mathrm{~mol} / \mathrm{L}$, ДБФ в виде сфер разных размеров опускался на дно. Во всем объеме водного раствора КТ-ДБФ наблюдались опалесцирующие центры. При увеличении концентрации фталатов в спектрах поглощения наблюдался рост полосы на длине волны $275 \mathrm{~nm}$ (рис. 1, данные 6-9), характерной для ДБФ, а в спектрах люминесценции увеличение амплитуды в основной полосе свечения КТ (см. вставку на рис. 1).

Увеличение люминесценции КТ при взаимодействии с ДБФ, предположительно, обусловлено трансформацией лигандной оболочки KT InP/ZnS в результате встраивания фталатов в сольватное окружение. Гидрофобность молекул ДБФ приводит к их локализации в полости Онзагера КТ и улучшению пассивации ее поверхности (пассивирующий эффект ДБФ более эффективен, чем действие тиогликолевой кислоты).

Аналогичная зависимость была получена для случая водно-спиртового раствора (9:1), содержащего КТ $\mathrm{InP} / \mathrm{ZnS}$, при возрастающей концентрации фталатов. В этом случае образование рассеивающих центров шло медленнее, чем в водном растворе; при минимальной

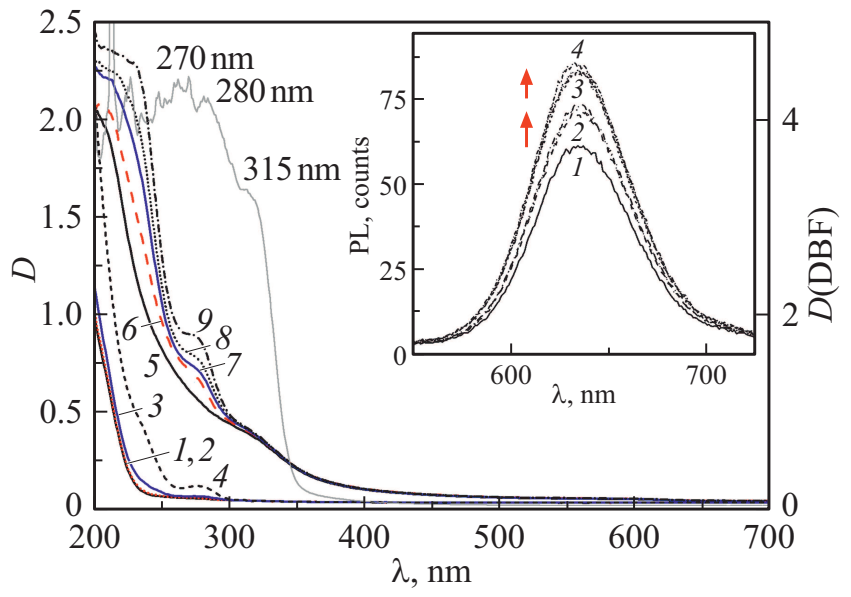

Рис. 1. Спектры поглощения: 1 - образец пресной воды; 2-4 - коллоидные растворы ДБФ с концентрациями $C_{2-4}=1.25,6.30$ и $12.50 \mathrm{mM} ; 5$ - раствор KT InP/ZnS; 6-9коллоидные растворы КТ-ДБФ с $C_{6-9}$ (ДБФ) $=1.25,6.30,18.75$ и $80.00 \mathrm{mM}$; серая кривая (ей соответствует шкала абсцисс справа) - спектр поглощения ДБФ. На врезке приведены спектры люминесценции: 1 - раствор КТ InP/ZnS; 2 - коллоидный раствор КТ-ДБФ с $C_{2}$ (ДБФ) $=1.25,2.50$ и $3.75 \mathrm{mM}$; 3 - раствор КТ-ДБФ с $C_{3}($ ДБФ) $=5.00,6.30$ и $18.75 \mathrm{mM} ; 4-$ раствор КТ-ДБФ с $C_{4}($ ДБФ) $=80.00 \mathrm{mM}$. Стрелки указывают направление увеличения концентрации ДБФ.

концентрации ДБФ (1.25 mM) фталат полностью растворился. При увеличении концентрации ДБФ процесс смешивания протекал аналогично описанному выше.

Обеспечивая одинаковое мольное содержание КТ в образцах с чистой водой и водой, содержащей фталаты, мы сравнили спектры поглощения и люминесценции КТ при возрастающей концентрации этанола (рис. 2). Отметим, что увеличение концентрации спирта в растворе с КТ приводило к разовому тушению люминесценции, связанному с разрушающим действием -OH- и $-\mathrm{CH}-$ групп спирта на PEG-COOH-лиганды, приведшему к частичному осаждению КТ. В присутствии же ДБФ при увеличении концентрации спирта интенсивность люминесценции КТ росла (рис. 2, $b$, данные 4-7), как и в случае водного раствора КТ (вставка на рис. 1). Последнее говорит о том, что содержание спирта в воде увеличивает растворимость фталатов.

Для всех рассмотренных случаев положение максимума люминесценции КТ соответствовало длине волны $\lambda=636 \mathrm{~nm}$ и не сдвигалось с увеличением концентрации фталатов. Полуширина спектра люминесценции на полувысоте составляла $62 \pm 5 \mathrm{~nm}$.

\section{Исследование взаимодействия КТ и ДБФ в морской воде}

Исследования проводились для изначально двух составов КТ и КТ-ДБФ, растворенных в одном из образцов морской воды, к которым осуществлялись последовательные добавки этанола. Из спектров поглощения КТ 

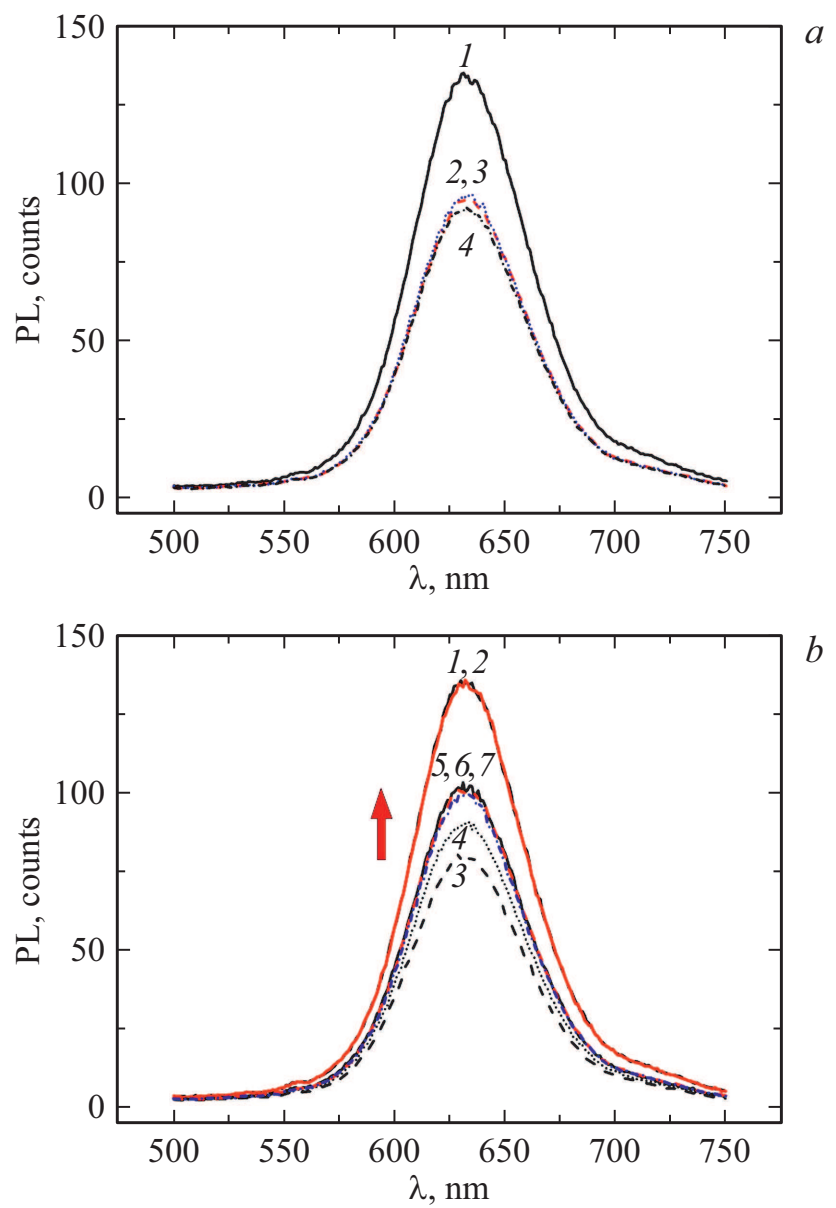

Рис. 2. Спектры люминесценции: 1 - коллоидный раствор КТ; (a) 2-4 - при добавлении 20, 40 и $80 \mu \mathrm{L}$ этанола соответственно; (b) 2 - раствор КТ-ДБФ, $С$ (ДБФ) $=3.75 \mathrm{mM}$; 3-7 - раствор КТ-ДБФ при добавлении 20, 40, 80, 120 и $160 \mu \mathrm{L}$ этанола соответственно. Стрелка указывает направление увеличения концентрации этанола.

в морской воде следует практически одноступенчатое снижение оптической плотности независимо от объема добавленного спирта (рис. 3, данные 3,4). Наибольшее снижение оптической плотности наблюдалось в образце воды из Черного моря, наименьшее - в образце из Средиземного. Как и в случае пресной воды, снижение оптической плотности вызвано частичным осаждением КТ при сольватации их поверхности спиртом.

Для состава КТ-ДБФ при увеличении концентрации этанола в образце воды из Средиземного моря происходило увеличение полос поглощения на длинах волн $\lambda=226$ и $276 \mathrm{~nm}$, как это происходило в пресной воде (рис. 1, данные 6-9). Это подтверждает увеличение растворимости фталатов с увеличением доли спирта в растворе. Однако в образцах воды из Черного и Белого морей спектры поглощения КТ-ДБФ отличались: в Белом море с ростом содержания этанола спектры практически совпадали между собой с едва различимой изобестикой в области $246 \mathrm{~nm}$, в Черном море - шли ниже кривой поглощения раствора КТ-ДБФ по аналогии со спектрами 3 и 4, представленными на рис. 3. Для образцов воды из Белого и Черного морей характерных пиков поглощения ДБФ не наблюдалось. Полученные спектры поглощения свидетельствуют о заметной зависимости растворимости фталатов от исходного состава воды. Содержащиеся в образцах воды Белого и Черного морей агенты, природа которых требует тщательного исследования, скрывали растворимость фталатов или же препятствовали ей. В этом смысле вода из Средиземного моря оказалась ближе к пресной.

По-разному реагировала на увеличение объемной доли спирта в образцах морской воды и люминесценция

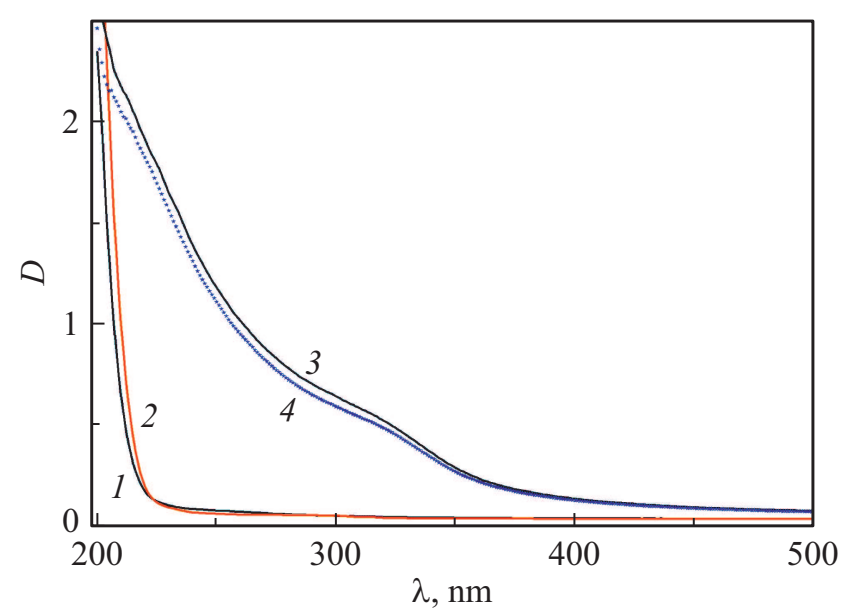

Рис. 3. Спектры поглощения: 1 - образец воды из Черного моря; 2 - образец воды из Средиземного моря; 3 - коллоидный раствор КT InP/ZnS в образце воды из Черного моря; 4 раствор КТ в образце воды из Черного моря при добавлении $40-120 \mu \mathrm{L}$ этанола.

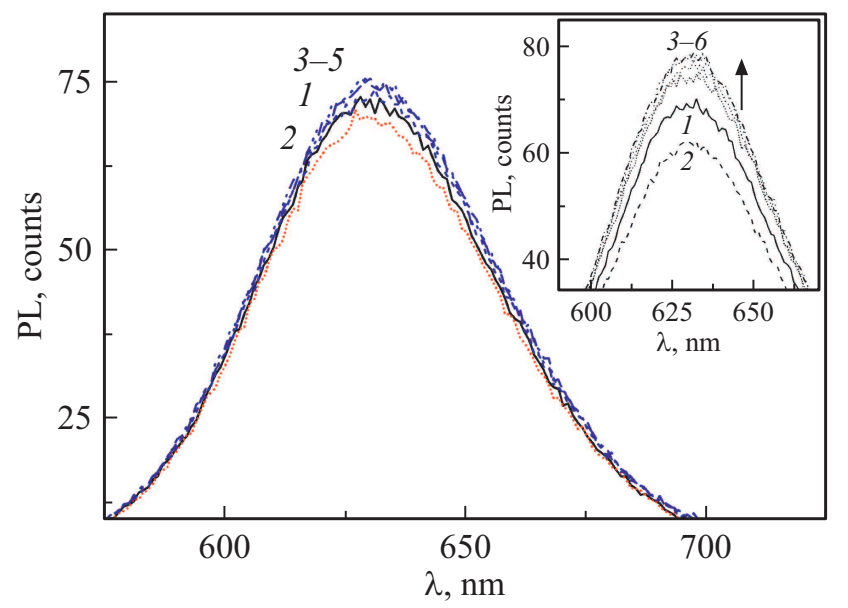

Рис. 4. Спектры люминесценции образца воды из Черного моря. 1 - коллоидный раствор КТ; 2 - раствор КТ-ДБФ; 3-5 растворы КТ-ДБФ, содержащие 40,80 и $120 \mu \mathrm{L}$ этанола. На врезке: 1 - раствор КТ; 2 - раствор КТ InP/ZnS через $30 \mathrm{~min}$; 3 - раствор КТ при последовательном добавлении 20, 40, 80 и $120 \mu \mathrm{L}$ этанола. Стрелка указывает направление увеличения концентрации этанола. 


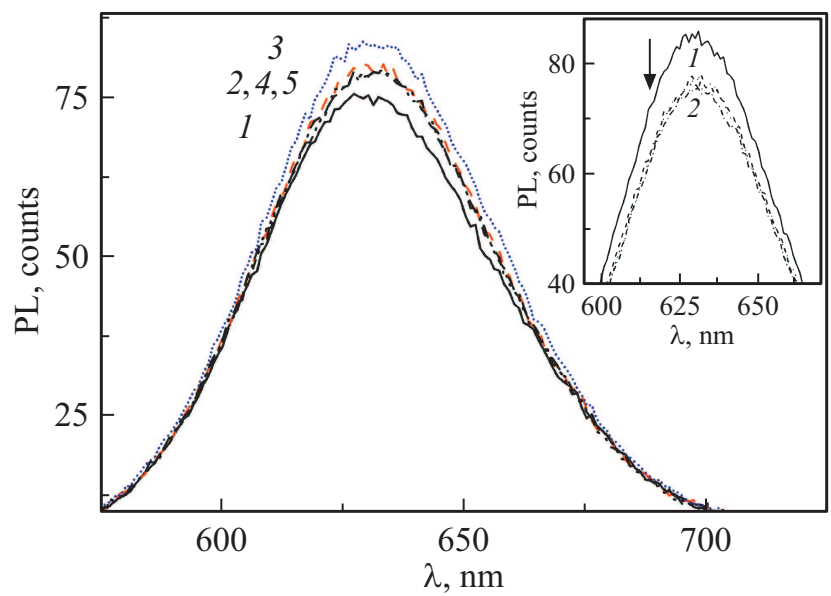

Pис. 5. Спектры люминесценции в образце воды из Средиземного моря: 1 - коллоидный раствор КТ; 2 - КТ-ДБФ; 3 раствор КТ-ДБФ, содержащий $40 \mu \mathrm{L}$ этанола; 4, 5 - растворы КТ-ДБФ при добавлении 80 и $120 \mu \mathrm{L}$ этанола. На врезке: 1 - раствор КТ; 2 - раствор КТ при последовательном добавлении 20, 40, 80 и $120 \mu \mathrm{L}$ этанола.

КТ (рис. 4,5). Для образцов Белого и Средиземного морей спектры люминесценции исходных растворов КТ коррелировали со спектрами поглощения в пресной воде, а именно наблюдалось одноступенчатое снижение амплитуды люминесценции КТ при увеличении концентрации этанола в растворах по аналогии с раствором пресной воды (см. вставку на рис. 5). В образце же из Черного моря наблюдалась более сложная картина: через $30 \mathrm{~min}$ после растворения КТ интенсивность свечения самопроизвольно уменьшилась, а при добавлении этанола начала расти (см. врезку на рис. 4). Такая реакция на увеличение доли спирта в растворе повторила картину на рис. $2, b$, сходную с наблюдавшейся при перестройке лигандной оболочки, т.е. при замене тиогликолевых лигандов на фталаты. Таким образом, можно предположить, что вода из Черного моря уже содержала некоторое количество фталатов.

Для состава КТ-ДБФ спектры люминесценции в образце Средиземного моря похожи на спектры в пресной воде (рис. $2, b$ ), за исключением высоких концентраций этанола, когда амплитуда люминесценции начала снижаться (рис. 5).

Для состава КТ-ДБФ в образце воды из Белого моря наблюдалось последовательное тушение люминесценции КТ при добавлении спирта по аналогии с приведенными данными на вставке рис. 5. Здесь проявилось отличие от образцов Средиземного и Черного морей, в которых наблюдался схожий механизм перестройки сольватных оболочек КТ при добавлении ДБФ.

Исследования взаимодействия КТ с ДБФ в образцах морской воды представляют собой комплексную задачу. Проведенный выше анализ свидетельствует о разном содержании фталатов в морских акваториях. Предположительно, наибольшее содержание ДБФ можно об- наружить в районе г. Геленджик, а наименьшее - в водах острова Гозо. Полученные результаты в целом могут быть использованы при разработке технических требований к аппаратуре экспресс-контроля содержания фталатов в водных средах. Помимо прикладного значения данное исследование вносит заметный вклад в изучение фотолюминесценции гибридных систем на основе квантовых точек InP/ZnS.

\section{Выводы}

В ходе исследований обнаружено, что увеличение концентрации ДБФ в растворе пресной воды с КТ $\mathrm{InP} / \mathrm{ZnS}$ приводит к росту амплитуды люминесценции КТ, увеличение концентрации этилового спирта в растворе пресной воды с КТ и ДБФ приводит к росту амплитуды люминесценции КТ. Исследования в образцах морской воды (Черного, Средиземного и Белого морей) показали различную динамику люминесценции коллоидных растворов КТ-ДБФ при увеличении концентрации этанола.

Установлено, что пластиковая упаковка, содержащая внутри себя вещества, в составе которых присутствует спирт, является потенциально опасной для здоровья человека. Увеличение амплитуды люминесценции КТ InP/ZnS при увеличении концентрации ДБФ в воде может выступать критерием его количественного содержания в воде. При регистрации фталатов добавление этилового спирта может повысить чувствительность метода.

\section{Финансирование работы}

Экспериментальные исследования были проведены при поддержке внутреннего гранта АО „ГОИ им. С.И. Вавилова“ для молодых ученых 2015г. Содержательная часть работы выполнена при поддержке Министерства науки и высшего образования в части Государственного задания № 0791-2020-0003.

\section{Конфликт интересов}

Авторы заявляют, что у них нет конфликта интересов.

\section{Список литературы}

[1] Bošnir J., Puntarić D., Galić A., Škes I., Dijanić T., Klarić M., Grgić M., Curković M., Šmit Z. // Food Techol. Biotechnol. 2007. V. 45. P. 91.

[2] Government of Canada. Phthalates (retrieved 11 July 2019). [Электронный ресурс] Режим доступа: https://www.canada.ca/en/health-canada/services/ chemicals-product-safety/phthalates.html

[3] Technical Regulations of the Customs Union (TR CU 005/2011). On Packaging Safety. [Электронный pecypc] Peжим доступа: https://ec.europa.eu/food/sites/food/files/ safety/docs/ia_eu-ru_sps-req_decision-769_16082011_en.pdf 
[4] Zaikab G.D. // Nature. 2011. doi 10.1038/news.2011.191

[5] Karnazhitskaya T.D., Antipyeva M.V., Zavernenkova E.O. // Aktualnyye problemy bezopasnosti i otsenki riska zdorovyu naseleniya pri vozdeystvii faktorov sredy obitaniya. Vserossiyskaya nauch.-prakt. Konferentsiya s mezhdunarodnym uchastiyem. Perm, 2014. P. 531 [in Russ.].

[6] Sфrensen L.K. // Rapid Commun. Mass Spectrom. 2006. V. 20. P. 1135. doi $10.1002 / \mathrm{rcm} .2425$

[7] Danilov V.V., Panfutova A.S., Khrebtov A.I., Ambrosini S., Videnichev D.A. // Opt. Lett. 2012. V. 37. N 19. P. 3948. doi 10.1364/OL.37.003948

[8] Bodunov E.N., Danilov V.V., Panfutova A.S., Simões Gamboa A.L. // Ann. Phys. (Berlin). 2016. V. 528. N 3-4. P. 272 277. doi 10.1002/andp.201500350

[9] Litvinov I.K., Belyaeva T.N., Salova A.V., Aksenov N.D., Leontieva E.A., Orlova A.O., Kornilova E.S. // Cell and Tissue Biology. 2018. V. 12. P. 135. doi 10.1134/S1990519X18020050 